Original Research Paper

\title{
Association Between Climatic Factors with Fresh Semen Quality Parameters in Madura Cattle (an Indonesian Native Breed)
}

\author{
${ }^{1}$ Nurul Isnaini, ${ }^{1}$ Bela Dwi Wadi Lestari, ${ }^{1}$ Faizal Andri, ${ }^{2}$ Tri Harsi and ${ }^{2}$ Eros Sukmawati \\ ${ }^{I}$ Faculty of Animal Science, Brawijaya University, Malang, Indonesia \\ ${ }^{2}$ Lembang Artificial Insemination Center, Bandung, Indonesia
}

\author{
Article history \\ Received: 29-04-2021 \\ Revised: 10-07-2021 \\ Accepted: 19-07-2021 \\ Corresponding Author: \\ Nurul Isnaini, \\ Faculty of Animal Science, \\ Brawijaya University, Malang, \\ Indonesia \\ Email: nurulisna@ub.ac.id
}

\begin{abstract}
Semen quality is a critical point to ensure the success of the artificial insemination program. One factor which highly determine the semen quality of bulls is climatic conditions. The purpose of the present study was to evaluate the association between climatic factors and fresh semen quality parameters in Madura bulls. A total of 1583 ejaculates which were collected from 5 Madura bulls from January 2014 to December 2018 were included in this study. Semen quality parameters such as semen Volume (VOL), sperm Concentration (CONC), Total sperm (TOT), sperm Motility (MOT) and Straw production (STR) were directly evaluated upon collection and then correlated with climate factors such as mean and maximum ambient temperature $\left(\mathrm{AT}_{\text {mean }}\right.$ and $\mathrm{AT}_{\max }$, respectively), Relative Humidity $(\mathrm{RH})$ and Temperature-Humidity Index (THI). The results demonstrated that the month of semen collection had no effect $(\mathrm{P}>0.05)$ on VOL, CONC and TOT. However, MOT and STR were differed $(\mathrm{P}<0.05)$ among semen collection time, with the peak value was observed in March. Among climatic variables studied here, $\mathrm{AT}_{\max }$ was the most sensitive factor associated with sperm quality parameters. $\mathrm{AT}_{\max }$ value at the same month as semen collection had negative significant correlation $(\mathrm{P}<0.05)$ with TOT and STR, while at one and two months before semen collection was consistently had negative significant correlation $(\mathrm{P}<0.01)$ with CONC, TOT and STR. It could be concluded that the maximum ambient temperature is the most responsible climatic factor affecting loss of straw production in Madura bulls.
\end{abstract}

Keywords: Artificial Insemination, Beef Cattle, Indonesian Local Cattle, Semen Cryopreservation, Tropical Region

\section{Introduction}

Madura cattle have been recognized as one of the Indonesian native breeds (KMPN, 2010). This breed is a result of crossing between Bali cattle (Indonesian origin breed) and Zebu cattle (Indian origin breed) which occur approximately 1,500 years ago in Madura Island, Indonesia (Sutarno and Setyawan, 2016). Madura cattle have predominantly brick red of body color with the white color in legs and rump (Sutarno and Setyawan, 2015). In addition, they also have small and short horn led to the outside (Maylinda et al., 2017). The population of Madura cattle are mostly concentrated in Madura Island, Indonesia (Zuhri et al., 2019). Due to their good adaptability to the tropical environment, Madura cattle are expected could contribute significantly to fulfill national meat demand. However, it was reported that Madura cattle population was still remained low, which only contribute to about $5.16 \%$ of the total cattle population (Sutarno and Setyawan, 2015). For that reason, the use of advanced technology such as Artificial Insemination (AI) is necessary to improve the productivity of Madura cattle.

The good semen quality is a critical point to ensure the success of the AI program. While semen quality itself is highly dependent on climate factors such as Ambient Temperature (AT), Relative Humidity (RH), or their combination as Temperature-Humidity Index (THI) 
(Snoj et al., 2013; Bhakat et al., 2014; Valeanu et al., 2015; Sabés-Alsina et al., 2017; Isnaini et al., 2019a; Isnaini et al., 2020; Isnaini et al., 2021a). Among those mentioned factors, AT seems to be the main variable which may affect semen quality. The increased in AT may induce heat stress, which strongly associated with the impairment of spermatogenesis and the reduction of sperm quality (Rahman et al., 2018). Since the duration of spermatogenesis in cattle is approximately 60 days, the deleterious effect of high AT is not sufficient to be observed only at the same time of semen collection (Sabés-Alsina et al., 2019). Currently, the information about the relationship between climatic variables and dynamic change of semen quality in Madura bulls is still very limited. Therefore, the present study was carried out to elaborate the association between climatic factors, either at the same month as, one month before, or two months before semen collection with fresh semen quality parameters in Madura bulls.

\section{Materials and Methods}

\section{Experimental Site and Climatic Factors}

This study was conducted at Lembang AI Center (Bandung, Indonesia), which was situated at $6.82^{\circ} \mathrm{S}$ $107.63^{\circ} \mathrm{E}$. The elevation of this site is about $1,241 \mathrm{~m}$ above sea level. The data of mean and maximum ambient temperature $\left(\mathrm{AT}_{\text {mean }}\right.$ and $\left.\mathrm{AT}_{\max },{ }^{\circ} \mathrm{C}\right)$ and relative humidity (RH, \%) were obtained from Bandung Geophysics Station, which was located approximately $11 \mathrm{~km}$ from the bull station. The Temperature-Humidity Index (THI) were calculated with a formula of THI $=0.8 \times \mathrm{AT}_{\text {mean }}$ $+(\mathrm{RH} / 100) \times\left(\mathrm{AT}_{\text {mean }}-14.4\right)+46.4$.

\section{Animals and Feeding}

A total of five Madura bulls were included in the study. The age of bulls at the beginning of the study was ranged from two to four years. The selection of bull was carried out by taking into account the performance of Madura cattle based on the Indonesian National Standard (SNI 7651.2: 2013). The selected bull must also be in good health, free from infectious animal diseases and free from physical and reproductive organs defects. The semen quality of bulls also should meat the Indonesian National Standard (SNI 4869-1: 2017)

The bulls were reared with similar management practices under standard protocol in Lembang AI center. Each of the bull was kept in an individual cage. The bulls were provided with constant feeding during experimental period. The daily ration consisted of $40 \mathrm{~kg}$ elephant grass (Pennisetum purpureum), $1 \mathrm{~kg}$ African grass hay (Cynodon plectostachyus), $3 \mathrm{~kg}$ commercial concentrate feed and $300 \mathrm{~g}$ mung bean sprout (Vigna radiata). The commercial concentrate feed had $16 \%$ crude protein content and $65 \%$ total digestible nutrient. The drinking water was provided ad libitum throughout the study.

\section{Semen Collection and Evaluation}

The semen collection was conducted twice a week from January 2014 to December $2018(n=1583)$. Upon collection, the semen quality parameters were directly evaluated for semen Volume (VOL) using a scaled tube (Kusumawati et al., 2018). After that, sperm Concentration (CONC) was measured using a spectrophotometer (Isnaini et al., 2019b). Total sperm (TOT) was calculated by VOL x CONC (Isnaini et al., 2019c). Individual motility (MOT) was evaluated using a phase contrast microscope (Deonizio et al., 2018). The ejaculates with MOT $>70 \%$ were included in the straw production (STR) calculation with a formula of TOT/25 million (Isnaini et al., 2019c).

\section{Statistical Analysis}

All statistical procedures were performed using SPSS ver. 13 software (SPSS Inc., Chicago, IL, USA). Data of semen quality were evaluated using analysis of variance with the month of semen collection as a factor. Duncan's multiple range test (Duncan, 1955) was employed to compare means, with statistical significant was set at $\mathrm{P}<0.05$. Relationship between climatic factors and semen quality parameters were evaluated using Pearson correlation test (Pearson, 1931).

\section{Results}

\section{Climatic Factors}

Figure 1 shows the monthly climatic factors in the experimental site throughout the study. $\mathrm{AT}_{\text {mean }}$ was ranged from 22.9 to $25.3^{\circ} \mathrm{C}$ with variation coefficient of $2.05 \%$. $\mathrm{AT}_{\max }$ was ranged from 26.6 to $31.9^{\circ} \mathrm{C}$ with variation coefficient of $2.97 \%$. $\mathrm{AT}_{\max }$ was relatively higher in September and October, but relatively lower in January and February. RH was ranged from 62.6 to $83.8 \%$ with variation coefficient of $6.89 \%$. THI was ranged from 70.4 to 75 with variation coefficient of $1.17 \%$.

\section{Semen Quality Parameters}

Table 1 shows the semen quality parameters of Madura bulls from 2014 to 2018. The overall mean values of VOL, CONC, TOT, MOT and STR were $5.31 \mathrm{~mL} /$ jaculate, 1.04 billion/mL, 5.43 billion/ejaculate, $63.9 \%$ and 169 unit/ejaculate, respectively. The month of semen collection did not affect $(\mathrm{P}>0.05)$ VOL, CONC and TOT, while MOT and STR were affected $(\mathrm{P}<0.05)$. The lowest MOT was recorded in July, while the higher value in March and December. In the case of STR, the lower value was observed in January, July, August and November, while the peak value in March. 

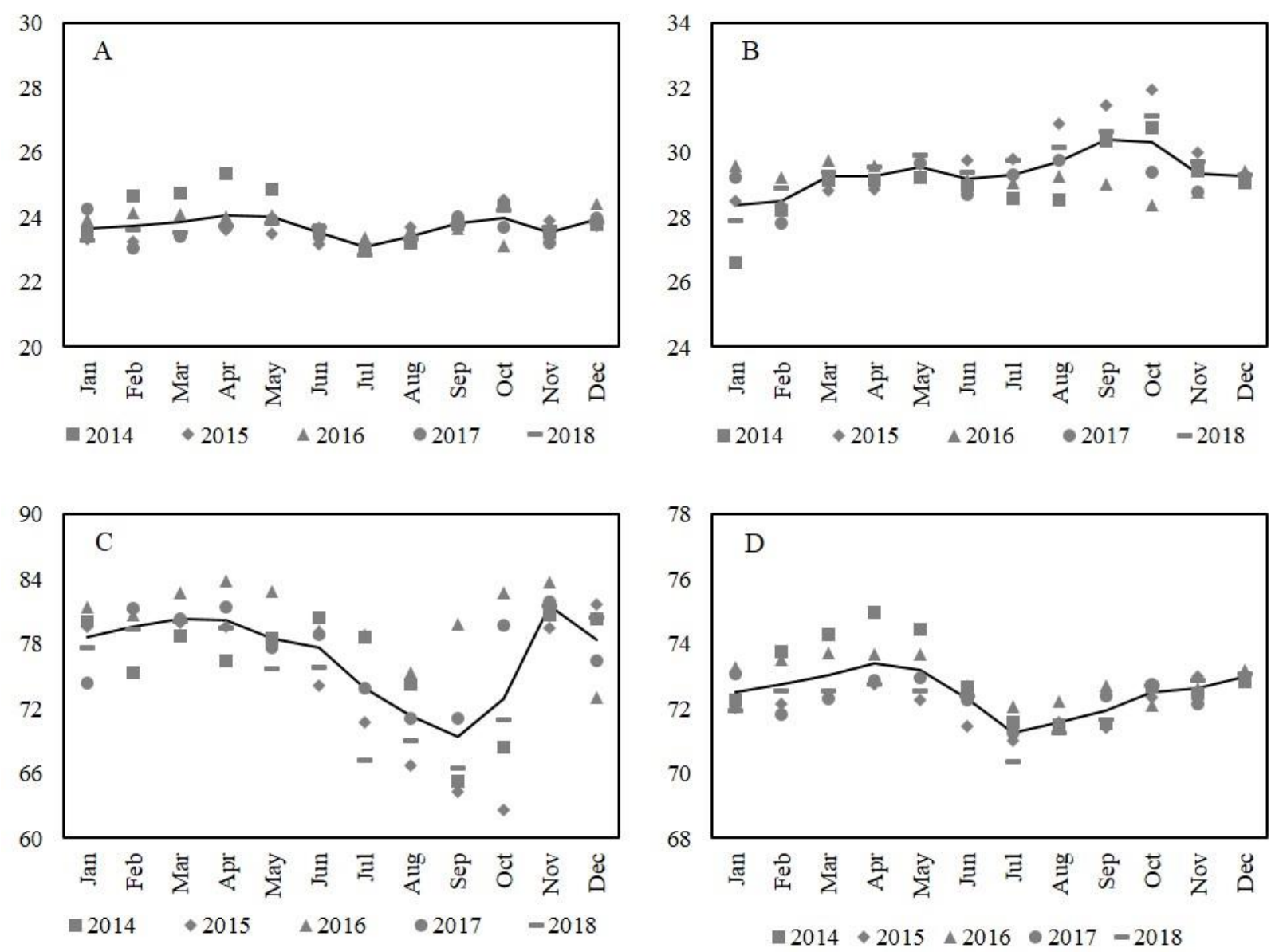

Fig. 1: Monthly climatic factors from January 2014 to December 2018 in Bandung, Indonesia. A: Mean ambient temperature $\left(\mathrm{AT}_{\text {mean }},{ }^{\circ} \mathrm{C}\right), \mathrm{B}$ : Maximum ambient temperature $\left(\mathrm{AT}_{\max },{ }^{\circ} \mathrm{C}\right), \mathrm{C}$ : Relative Humidity $(\mathrm{RH}, \%)$, D: Temperature-humidity index (THI). (-) Black line inside the graph represents mean values from 2014 to 2018.

Table 1: Summary of semen quality parameters (mean \pm SE) of Madura bulls

\begin{tabular}{lllllll}
\hline Month & $\mathrm{n}$ & VOL & CONC & TOT & MOT & STR \\
\hline January & 141.00 & $5.09 \pm 0.14$ & $0.96 \pm 0.03$ & $4.9 \pm 0.19$ & $62.9 \pm 1.18^{\mathrm{abcd}}$ & $151 \pm 10.4^{\mathrm{a}}$ \\
February & 120.00 & $5.58 \pm 0.18$ & $1.06 \pm 0.03$ & $5.75 \pm 0.21$ & $65.9 \pm 0.89^{\mathrm{cd}}$ & $194 \pm 11.5^{\mathrm{bc}}$ \\
March & 145.00 & $5.46 \pm 0.13$ & $1.08 \pm 0.03$ & $5.79 \pm 0.18$ & $66.1 \pm 0.86^{\mathrm{d}}$ & $196 \pm 9.92^{\mathrm{c}}$ \\
April & 111.00 & $5.24 \pm 0.15$ & $1.04 \pm 0.03$ & $5.38 \pm 0.22$ & $64.2 \pm 1.1^{\mathrm{abcd}}$ & $171 \pm 12.2^{\mathrm{abc}}$ \\
May & 104.00 & $5.68 \pm 0.18$ & $1.04 \pm 0.03$ & $5.76 \pm 0.2$ & $65.4 \pm 1.06^{\mathrm{cd}}$ & $189 \pm 11.4^{\mathrm{bc}}$ \\
June & 118.00 & $5.43 \pm 0.16$ & $1.04 \pm 0.03$ & $5.56 \pm 0.21$ & $61.7 \pm 1.22^{\mathrm{ab}}$ & $161 \pm 12.4^{\mathrm{ab}}$ \\
July & 147.00 & $5.22 \pm 0.15$ & $1.13 \pm 0.09$ & $5.85 \pm 0.49$ & $61.3 \pm 1.17^{\mathrm{a}}$ & $152 \pm 10.3^{\mathrm{a}}$ \\
August & 163.00 & $5.18 \pm 0.13$ & $1.04 \pm 0.02$ & $5.28 \pm 0.16$ & $62.5 \pm 1.02^{\mathrm{abc}}$ & $153 \pm 9.97^{\mathrm{a}}$ \\
September & 122.00 & $5.01 \pm 0.13$ & $1.07 \pm 0.03$ & $5.28 \pm 0.17$ & $64.9 \pm 0.9^{\mathrm{bcd}}$ & $160 \pm 10.9^{\mathrm{ab}}$ \\
October & 158.00 & $5.32 \pm 0.15$ & $1 \pm 0.03$ & $5.33 \pm 0.2$ & $64.2 \pm 0.99^{\mathrm{abcd}}$ & $168 \pm 10.4^{\mathrm{abc}}$ \\
November & 125.00 & $5.23 \pm 0.15$ & $0.98 \pm 0.03$ & $5.06 \pm 0.2$ & $62.8 \pm 1.23^{\mathrm{abcd}}$ & $153 \pm 10.7^{\mathrm{a}}$ \\
December & 129.00 & $5.41 \pm 0.14$ & $1 \pm 0.03$ & $5.36 \pm 0.18$ & $66 \pm 0.99^{\mathrm{d}}$ & $184 \pm 9.99^{\mathrm{abc}}$ \\
P value & & 0.08 & 0.113 & 0.083 & 0.002 & 0.003 \\
\hline
\end{tabular}

n: Number of ejaculates, VOL: Semen volume (ml/ejaculate), CONC: Sperm concentration (billion/ml), TOT: Total sperm (billion/ejaculate), MOT: Individual motility (\%), STR: Straw production (unit/ejaculate)

${ }^{\mathrm{a}-\mathrm{d}}$ different superscript letters denote significant difference among months of semen collection $(\mathrm{P}<0.05)$ 
Table 2: Relationship between climatic factors and semen quality parameters

\begin{tabular}{|c|c|c|c|c|c|}
\hline Items & VOL & CONC & TOT & MOT & STR \\
\hline \multicolumn{6}{|c|}{ Same month as semen collection } \\
\hline $\mathrm{AT}_{\text {mean }}$ & -0.01 & -0.05 & -0.05 & $0.05^{*}$ & 0.01 \\
\hline $\mathrm{AT}_{\max }$ & -0.05 & -0.03 & $-0.05^{*}$ & 0.01 & $-0.05 *$ \\
\hline $\mathrm{RH}$ & $0.1 * *$ & -0.02 & 0.05 & 0.03 & $0.08 * *$ \\
\hline THI & $0.06 *$ & $-0.05^{*}$ & -0.01 & $0.06^{*}$ & $0.06^{*}$ \\
\hline \multicolumn{6}{|c|}{ One month before semen collection } \\
\hline $\mathrm{AT}_{\text {mean }}$ & -0.01 & -0.02 & -0.02 & -0.03 & -0.03 \\
\hline $\mathrm{AT}_{\max }$ & -0.05 & $-0.08 * *$ & $-0.09 * *$ & -0.03 & $-0.09 * *$ \\
\hline $\mathrm{RH}$ & $0.09 * *$ & 0.04 & $0.08 * *$ & 0.02 & $0.08 * *$ \\
\hline THI & $0.05^{*}$ & 0.002 & 0.04 & -0.02 & 0.02 \\
\hline \multicolumn{6}{|c|}{ Two month before semen collection } \\
\hline $\mathrm{AT}_{\text {mean }}$ & -0.04 & 0.02 & -0.002 & -0.02 & -0.02 \\
\hline $\mathrm{AT}_{\max }$ & -0.03 & $-0.07 * *$ & $-0.07 * *$ & -0.03 & $-0.07 * *$ \\
\hline $\mathrm{RH}$ & $0.06^{*}$ & $0.05 *$ & $0.07 *$ & 0.02 & 0.04 \\
\hline THI & 0.01 & $0.05 *$ & 0.05 & -0.04 & 0.01 \\
\hline
\end{tabular}

*Significant correlation at $\mathrm{P}<0.05, * *$ Significant correlation at $\mathrm{P}<0.01$

\section{Relationship between Climatic Factors and Semen Quality Parameters}

Table 2 shows that there were several significant correlations between climatic factors at the same month as semen collection with semen quality parameters. The positive correlations were found on $\mathrm{AT}_{\text {mean }}$ with MOT $(\mathrm{P}<0.05)$, RH with VOL and STR $(\mathrm{P}<0.01)$ and THI with VOL, MOT and STR $(\mathrm{P}<0.05)$, whereas, the negative correlations were found on $\mathrm{AT}_{\max }$ with $\mathrm{TOT}$ and STR $(\mathrm{P}<0.05)$, as well as THI with $\mathrm{CONC}(\mathrm{P}<0.05)$. There were also several significant correlations between climatic factors at one month before semen collection with semen quality parameters. RH had positive correlations with VOL, TOT and STR $(\mathrm{P}<0.01)$. THI also positively correlated with VOL $(\mathrm{P}<0.05)$. On the other hand, $\mathrm{AT}_{\max }$ was negatively correlated with CONC, TOT and STR $(\mathrm{P}<0.01)$. In addition, several significant correlations between climatic factors at two months before semen collection with semen quality parameters were also detected in this study. At this time point, the positive correlations were found on $\mathrm{RH}$ with VOL, CONC and TOT $(\mathrm{P}<0.05)$ and THI with CONC $(\mathrm{P}<0.05)$. While, the negative correlations were found on $\mathrm{AT}_{\max }$ with CONC, TOT and STR $(\mathrm{P}<0.01)$.

\section{Discussion}

In this study, the climatic variables could be categorized as stable due to the low variation coefficient value throughout the experiment. It was also previously reported that in Semarang, Indonesia (another location of Indonesian $\mathrm{AI}$ center), the $\mathrm{AT}_{\text {mean }}$ and $\mathrm{RH}$ were almost equal throughout the year, with $26.6^{\circ} \mathrm{C}$ and $82.3 \%$ in rainy season and $26.9^{\circ} \mathrm{C}$ and $81.5 \%$ in dry season (Isnaini et al., 2019d), In another study, Brito et al. (2002) reported that the average $\mathrm{AT}_{\text {mean }}$ and $\mathrm{RH}$ in a Brazilian $\mathrm{AI}$ center were ranged from 19.5 to $25.7^{\circ} \mathrm{C}$ $\left(\right.$ mean $\left.=23.4^{\circ} \mathrm{C}\right)$ and 60.9 to $81.4 \%($ mean $=71.4 \%)$.
The overall mean values of sperm quality parameters obtained in this study were almost comparable to those reported by Ratnawati et al. (2018), who observed that the VOL, CONC, MOT of Madura bulls were $5.7 \mathrm{~mL} / \mathrm{ejaculate,}$ 1.08 billion $/ \mathrm{mL}$ and $66 \%$. In comparison with other Indonesian native breeds, Madura bulls used in this study relatively had higher VOL but with lower CONC than Ongole Grade and Bali bulls (Kusumawati et al., 2017; Susilawati et al., 2018). Whereas, Madura bulls relatively had lower VOL but with higher CONC when compared with Pasundan bulls (Isnaini et al., 2021b).

No difference among semen collection time toward VOL, CONC and TOT was consistent with previous findings. Brito et al. (2002) noted that there was no significant effect of the month on VOL, CONC and TOT of breeding bulls raised in the tropical area of Brazil with only less than $2 \%$ of variation among the months. Similarly, Isnaini et al. (2019d) also found that VOL, CONC and TOT of Simmental bulls were remained unchanged during rainy and dry seasons. In another study, Landaeta-Hernández et al. (2020) also reported that the season of collection had no significant effect on CONC of crossbred bulls. Although the variation in MOT and STR exists in the present finding, the semen collection is still acceptable to be conducted throughout the year. In the case of the peak STR which is achieved in March, this evidence probably as a reflection of the lower $\mathrm{AT}_{\max }$ in January and February, which allow more ideal condition for spermatogenesis. On the other hand, when $\mathrm{AT}_{\max }$ reaching its high points, such as in September and October, the reduction in STR is observed in November.

This current study demonstrated that $\mathrm{AT}_{\max }$ represents as the most sensitive factor associated with sperm quality parameters. $\mathrm{AT}_{\max }$ value at all-time points consistently had negative significant correlations with TOT and STR. It could be explained that the increased in environmental temperature led to the increased in scrotal temperature, 
which even in only a small degree or at a short period, could generate oxidative stress (Alves et al., 2016; Boe-Hansen et al., 2020). The oxidative stress then may interfere productive and reproductive response, as well as decreasing TOT (Brito et al., 2003; Nichi et al., 2006; Andri et al., 2016; De Ruediger et al., 2016; Andri et al., 2018). Since TOT data are used as the basis of STR calculation, their reduction will be followed by the latter.

In this study, the higher correlation value (r) between $\mathrm{AT}_{\max }$ with CONC, TOT and STR were detected at one month before semen collection, which indicates that the spermatogenesis stage at this time point is more susceptible to heat stress rather than at the same month as or two months before semen collection. This result probably due to the adverse effect of heat stress was more pronounced at spermiogenesis and meiosis phases, as previously elaborated by Rahman et al. (2011) that the peak proportion of sperm with low protamine content due to the heat stress induction was found at days 28 to 35 of spermatogenesis. The low protamine content could contribute to the DNA damage (Fortes et al., 2014), which may further be associated with the decreased in CONC (Schulte et al., 2010) and consequently will be followed by the reduction in TOT and STR.

\section{Conclusion}

In conclusion, the maximum ambient temperature is the most responsible climatic factor affecting loss of straw production in Madura bulls.

\section{Acknowledgement}

The authors are gratefully acknowledged research facility support provided by Lembang Artificial Insemination Center (Bandung, Indonesia).

\section{Author's Contributions}

Nurul Isnaini: Conception and design, analysis and interpretation of data, reviewing manuscript critically for significant intellectual content and give final approval of the version to be submitted and any revised version.

Bela Dwi Wadi Lestari and Faizal Andri: Conception and design, acquisition of data, analysis and interpretation of data, drafting the manuscript and give final approval of the version to be submitted and any revised version.

Tri Harsi and Eros Sukmawati: Conception and design, acquisition of data, reviewing manuscript critically for significant intellectual content and give final approval of the version to be submitted and any revised version.

\section{Ethics}

The authors declare that there are no ethical issues may arise after the publication of this study.

\section{References}

Alves, M. B. R., de Andrade, A. F. C., de Arruda, R. P., Batissaco, L., Florez-Rodriguez, S. A., de Oliveira, B. M. M., ... \& Celeghini, E. C. C. (2016). Recovery of normal testicular temperature after scrotal heat stress in rams assessed by infrared thermography and its effects on seminal characteristics and testosterone blood serum concentration. Theriogenology, 86(3), 795-805. https://www.sciencedirect.com/science/article/abs/pi i/S0093691X16001060

Andri, F., Sukoco, A., Hilman, T., \& Widodo, E. (2016). Effect of adding tomato powder to fish oil-containing diet on performance and egg quality of native laying hens. Lives. Res. Rural Dev, 28, 12. http://www.lrrd.org/lrrd28/12/andr28221.html

Andri, F., Widodo, E., \& Djunaidi, I. H. (2018). Effects of dietary sardine oil and tomato powder supplementation on laying performance and egg quality of Mojosari duck. Livest. Res. Rural Dev, 30(2), 32. http://www.lrrd.org/lrrd30/2/faiz30032.html

Bhakat, M., Mohanty, T. K., Gupta, A. K., \& Abdullah, M. (2014). Effect of season on semen quality of crossbred (Karan Fries) bulls. Adv. Anim. Vet. Sci, 2(11), 632-637.

https://pdfs.semanticscholar.org/4427/6966a2694d0 52324866f835554f5d29a2b79.pdf

Boe-Hansen, G. B., Rêgo, J. P. A., Satake, N., Venus, B., Sadowski, P., Nouwens, A., ... \& McGowan, M. (2020). Effects of increased scrotal temperature on semen quality and seminal plasma proteins in Brahman bulls. Molecular Reproduction and Development, 87(5), 574-597. https://onlinelibrary.wiley.com/doi/abs/10.1002/mrd.23 328

Brito, L. F., Silva, A. E., Barbosa, R. T., Unanian, M. M., \& Kastelic, J. P. (2003). Effects of scrotal insulation on sperm production, semen quality and testicular echotexture in Bos indicus and Bos indicus $\times$ Bos taurus bulls. Animal Reproduction Science, 79(1-2), 1-15 https://www.sciencedirect.com/science/article/pii/S0 378432003000824

Brito, L. F. C., Silva, A. E. D. F., Rodrigues, L. H., Vieira, F. V., Deragon, L. A. G., \& Kastelic, J. P. (2002). Effects of environmental factors, age and genotype on sperm production and semen quality in Bos indicus and Bos taurus AI bulls in Brazil. Animal Reproduction Science, 70(3-4), 181-190. https://www.sciencedirect.com/science/article/abs/pi i/S037843200200009X

De Ruediger, F. R., Chacur, M. G. M., Alves, F. C. P. E., Oba, E., \& de Amorim Ramos, A. (2016). Digital infrared thermography of the scrotum, semen quality, serum testosterone levels in Nellore bulls (Bos taurus indicus) and their correlation with climatic factors. Semina: Ciências Agrárias, 37(1), 221-232. https://www.redalyc.org/pdf/4457/445744667021.pdf 
KMPN. (2010) Decree of Minister of Agriculture of the Republic of Indonesia Number.

3735/kpts/Hk.040/11/2010 regarding Determination of the Madura Cattle Clump (Indonesian). http://bibit.ditjenpkh.pertanian.go.id/sites/default/files/ Sapi\%20Madura.pdf

Deonizio, V., Sri, W., \& Isnaini, N. (2018). Effect of young coconut water and egg yolk extender ratio and length of storage at low temperature on sperm motility and viability of Bali bull. Russian Journal of Agricultural and Socio-Economic Sciences, 80(8). doi.org/10.18551/rjoas.2018-08.49

Duncan, D. B. (1955). Multiple range and multiple F tests. Biometrics, 11(1), 1-42. https://www.jstor.org/stable/3001478

Fortes, M. R., Satake, N., Corbet, D. H., Corbet, N. J., Burns, B. M., Moore, S. S., \& Boe - Hansen, G. B. (2014). Sperm protamine deficiency correlates with sperm DNA damage in B os indicus bulls. Andrology, 2(3), 370-378.

https://onlinelibrary.wiley.com/doi/abs/10.1111/j.20 47-2927.2014.00196.x

Indonesian National Standard (SNI 7651.2: 2013). Beef Cattle - Part 2: Madura Cattle (Indonesian). http://bibit.ditjenpkh.pertanian.go.id/sites/default/fil es/SNI\%207651.2-

2013\%20bibit\%20sapi\%20madura.pdf

Indonesian National Standard (SNI 4869-1:2017). Frozen Semen - Part 1: Cattle (Indonesian).

http://bibit.ditjenpkh.pertanian.go.id/sites/default/fil es/SNI\%204869-1-2017\%20Semen\%20beku\%20$\% 20$ Bagian\%201\%20Sapi.pdf

Isnaini, N., Harsi, T., \& Maharani, D. (2019a). Seasonal effect on semen characteristics of Murrah buffalo bulls raised under tropical climate. Jurnal Kedokteran Hewan, 13(3), 73-75.

https://pdfs.semanticscholar.org/f011/b110d7f09c31 f664f364521e39bb0e1c4cd7.pdf7

Isnaini, N., Wahjuningsih, S., \& Adhitama, E. (2019b). Seasonal effects on semen quality of Ongole crossbred and Simmental bulls used for artificial insemination. Livestock Research for Rural Development, 31(2), 16. http://www.lrrd.org/lrrd31/2/nurul31016.html

Isnaini, N., Wahjuningsih, S., Ma'ruf, A., \& Witayanto, D. A. (2019c). Effects of age and breed on semen quality of beef bull sires in an Indonesian artificial insemination center. Livestock Research for Rural Development, 31(5). http://lrrd.cipav.org.co/lrrd31/5/nurul31078.html

Isnaini, N., Wahjuningsih, S., \& Adhitama, E. (2019d). Seasonal effects on semen quality of Ongole crossbred and Simmental bulls used for artificial insemination. Livestock Research for Rural Development, 31(2), 16. http://www.lrrd.org/lrrd31/2/nurul31016.html
Isnaini, N., Ciptadi, G., Herwijanti, E., Walidah, N. I. P., \& Putra, M. W. S. N. (2020). Effects of seasons and environmental conditions on semen quality of Senduro goats reared under tropical climate. Turkish Journal of Veterinary and Animal Sciences, 44(3), 594-599 https://journals.tubitak.gov.tr/veterinary/abstract.htm ?id=27195

Isnaini, N., Wahjuningsih, S., Falah, M. M., Fajarrofa, A., Harsi, T., \& Sukmawati, E. (2021a). Seasonal variations on semen characteristics of fattailed and garut rams under TROPICAL CONDITIONS. Jurnal Kedokteran Hewan-Indonesian Journal of Veterinary Sciences, http://erepository.unsyiah.ac.id/JKH/article/view/15168

Isnaini, N., Harsi, T., Lapoliwa, A. D., Chabiburochman, M. M., \& Amarsyah, A. D. (2021b). Seasonal variations in semen quality of Pasundan bulls in their native tropical environment. American Journal of Animal and Veterinary Sciences, 16(2), 124-129. https://doi.org/10.3844/ajavsp.2021.124.129

Kusumawati, E. D., Isnaini, N., Yekti, A. P. A., Luthfi, M., Affandhy, L., Pamungkas, D., Kuswati, Ridhowi, A., Sudarwati, H., Susilawati, T., \& Rahayu, S. (2017). The spermatozoa quality of semen sexing of the filial Ongole cattle using percoll density gradient centrifugation method. Asian Journal of Microbiology, Biotechnology and Environmental Sciences, 19(1), 193-197.

http://www.envirobiotechjournals.com/article_abstra ct.php?aid=7739\&iid=227\&jid=1

Kusumawati, E. D., Rahadi, S., Isnaini, N., Wahjuningsih, S., Abdullah, A. G., Agustina, R., \& Susilawati, T. (2018, November). Effect of different extender on the quality of sexing sperm before freezing in limousin cattle. In IOP Conference Series: Materials Science and Engineering (Vol. 434, No. 1, p. 012102). IOP Publishing.

https://iopscience.iop.org/article/10.1088/1757899X/434/1/012102/meta

Landaeta-Hernández, A. J., Gil-Araujo, M. A., Ungerfeld, R., Rae, D. O., Urdaneta-Moyer, A., Parra-Núñez, A., ... \& Chenoweth, P. J. (2020). Effect of season and genotype on values for bull semen variables under tropical conditions. Animal Reproduction Science, 221, 106592.

https://www.sciencedirect.com/science/article/abs/pi i/S0378432020304644

Maylinda, S., Nugroho, H., \& Busono, W. (2017, May). Phenotypic characteristics of local cattle in Madura Island. In AIP Conference Proceedings (Vol. 1844, No. 1, p. 060002). AIP Publishing LLC. https://aip.scitation.org/doi/abs/10.1063/1.4983442 
Nichi, M., Bols, P. E. J., Züge, R. M., Barnabe, V. H., Goovaerts, I. G. F., Barnabe, R. C., \& Cortada, C. N. M. (2006). Seasonal variation in semen quality in Bos indicus and Bos taurus bulls raised under tropical conditions. Theriogenology, 66(4), 822-828. https://www.sciencedirect.com/science/article/abs/pi i/S0093691X06000720

Pearson, E. S. (1931). The test of significance for the correlation coefficient. Journal of the American Statistical Association, 26(174), 128-134. https://www.tandfonline.com/doi/abs/10.1080/0162 1459.1931.10503208? journalCode=uasa20

Rahman, M. B., Schellander, K., Luceño, N. L., \& Van Soom, A. (2018). Heat stress responses in spermatozoa: Mechanisms and consequences for cattle fertility. Theriogenology, 113, 102-112. https://www.sciencedirect.com/science/article/abs/pi i/S0093691X18300669

Rahman, M. B., Vandaele, L., Rijsselaere, T., Maes, D., Hoogewijs, M., Frijters, A., ... \& Van Soom, A. (2011). Scrotal insulation and its relationship to abnormal morphology, chromatin protamination and nuclear shape of spermatozoa in Holstein-Friesian and Belgian Blue bulls. Theriogenology, 76(7), 1246-1257. https://www.sciencedirect.com/science/article/abs/pi i/S0093691X11002652

Ratnawati, D. I. A. N., Isnaini, N. U. R. U. L., \& Susilawati, T. R. I. N. I. L. (2018). Character motility of liquid semen on Ongole crossbreed (PO), Bali and Madura bulls with different diluents at cold storage. Asian Journal of Microbiol Env, 20(1), 21-28. http://www.envirobiotechjournals.com/article_abstra ct.php?aid=8477\&iid=244\&jid=1

Sabés-Alsina, M., Johannisson, A., Lundeheim, N., Lopez-Bejar, M., \& Morrell, J. M. (2017). Effects of season on bull sperm quality in thawed samples in northern Spain. Veterinary Record, 180(10), 251-251. https://onlinelibrary.wiley.com/doi/pdf/10.1136/vr.103 897

Sabés-Alsina, M., Lundeheim, N., Johannisson, A., López-Béjar, M., \& Morrell, J. M. (2019). Relationships between climate and sperm quality in dairy bull semen: A retrospective analysis. Journal of dairy science, 102(6), 5623-5633. https://www.sciencedirect.com/science/article/pii/S0 022030219302838
Schulte, R. T., Ohl, D. A., Sigman, M., \& Smith, G. D. (2010). Sperm DNA damage in male infertility: Etiologies, assays and outcomes. Journal of assisted reproduction and genetics, 27(1), 3-12.

https://link.springer.com/article/10.1007/s10815009-9359-xSnoj

Snoj, T., Kobal, S., \& Majdic, G. (2013). Effects of season, age and breed on semen characteristics in different Bos taurus breeds in a 31-year retrospective study. Theriogenology, 79(5), 847-852.

https://www.sciencedirect.com/science/article/abs/pi i/S0093691X13000034

Susilawati, T. R. I. N. I. L., Ratnawati, D. I. A. N., Isnaini, N. U. R. U. L., Kuswati, K., \& Yekti, A. P. (2018). Character of liquid semen motility in various diluents on Balinese cattle during cold storage. Asian Journal of Microbiology, Biotechnology and Environmental Sciences, 20(1), 166-172.

http://www.envirobiotechjournals.com/article_abstra ct.php?aid=8497\&iid=244\&jid=1

SUTARNO, S., \& SETYAWAN, A. D. (2015). Genetic diversity of local and exotic cattle and their crossbreeding impact on the quality of Indonesian cattle. Biodiversitas Journal of Biological Diversity, 16(2). https://www.smujo.id/biodiv/article/view/75

SUTARNO, S., \& SETYAWAN, A. D. (2016). The diversity of local cattle in Indonesia and the efforts to develop superior indigenous cattle breeds. Biodiversitas Journal of Biological Diversity, 17(1). https://www.smujo.id/biodiv/article/view/124

Valeanu, S., Johannisson, A., Lundeheim, N., \& Morrell, J. M. (2015). Seasonal variation in sperm quality parameters in Swedish red dairy bulls used for artificial insemination. Livestock Science, 173, 111-118. https://doi.org/10.1016/j.livsci.2014.12.005

Zuhri, M. S., Ihsan, M. N., \& Isnaini, N. (2019). Evaluation of the reproductive performance of Madura cattle raised by small-scale farmers in Madura, Indonesia. Livestock Research for Rural Development, 31(5). https://www.cabdirect.org/cabdirect/abstract/201932 97682 